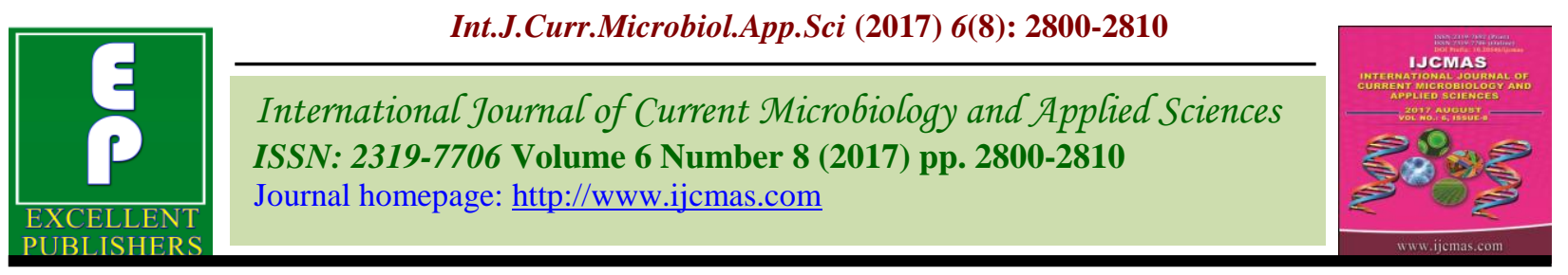

Original Research Article

https://doi.org/10.20546/ijcmas.2017.608.333

\title{
Precision Management Practices - A Much Needed Set of Agro-Techniques to Improve Rice Productivity and Cutback the Resources in Aerobic Condition under Drip Irrigation
}

\author{
D.S. Prabhudeva ${ }^{1 *}$, Nagaraju ${ }^{1}$, T. Sheshadri ${ }^{1}$, P.K. Basavaraja ${ }^{2}$, \\ M.N. Thimmegowda ${ }^{1}$ and G.B. Mallikarjuna ${ }^{3}$ \\ ${ }^{1}$ Department of Agronomy, ${ }^{2}$ Department of Soil Science and Agricultural Chemistry, \\ ${ }^{3}$ Department of Agricultural Statistics, GKVK, UAS, Bengaluru-65, Karnataka, India \\ *Corresponding author
}

A B S T R A C T

Keywords

Precision management practices, Aerobic rice, Planting geometry, Drip irrigation.

Article Info

Accepted:

23 June 2017

Available Online:

10 August 2017
A field experiment was conducted to assess the precision management practices on agronomic efficiency, grain yield, water productivity and economics of aerobic rice during summer 2016 and kharif 2016. Treatments comprising two nutrient management practices, three planting geometry and two water management practices with one control (soil application of fertilizer dose and drip irrigation) and one absolute control (No RDF and drip irrigation). The results revealed that, among interactions between nutrient management, planting geometry and water management, application of $25 \% \mathrm{~N} \& \mathrm{~K}$ from sowing to $30 \mathrm{DAS}+25 \% \mathrm{~N} \& \mathrm{~K}$ from 31 to $50 \mathrm{DAS}+25 \% \mathrm{~N} \& \mathrm{~K}$ from 51 to $80 \mathrm{DAS}+25 \% \mathrm{~N} \& \mathrm{~K}$ from 81 to $105 \mathrm{DAS}$ with planting geometry of $25 \times 15 \mathrm{~cm}$ and drip irrigation scheduling at $125 \%$ PE up to tillering $+150 \%$ PE from tillering to PI $+200 \%$ PE from PI to physiological maturity recorded significant grain yield $\left(8.56 \mathrm{t} \mathrm{ha}^{-1}\right)$, agronomic efficiency of nitrogen, phosphorus \& potassium $\left(62.87,125.74\right.$ and $125.74 \mathrm{~kg} \mathrm{~kg}^{-1}$, respectively) and net returns \& B:C ratio ( $\square 82,853$ and 2.47 , respectively) than soil application of fertilizers in aerobic rice.

\section{Introduction}

World agriculture is facing one of the largest challenges in the $21 \mathrm{st}$ century: how to produce enough food to feed 9 billion people by 2050 , with limited land, water and nutrient resources, and reduce negative environmental harm simultaneously for sustainable development (Tilman et al., 2011). This calls for a new paradigm of sustainable intensification of agriculture to close "yield gaps" of underperforming lands and increase resource use efficiencies simultaneously
(Shen et al., 2013). Precision agriculture (PA) has been listed as one of the top ten revolutions in agriculture for the past 50 years (Crookston, 2006). It can be defined as an integrated information- and technology-based agricultural management system, with the intent to manage spatial and temporal variability associated with all aspects of agricultural production for optimum profitability, sustainability and protection of the environment (Miao et al., 2006). It has 
been regarded as a promising strategy that can make significant contributions to both food security and sustainable development (Mueller et al., 2012). However, such precision agricultural systems do not exist yet and most PA research to date has mainly focused on nutrient (Peng et al., 2010), water (Hedley and Yule, 2009) and pesticide (Mahlein et al., 2012) management to improve resource use efficiencies. Such systems generally maintained or slightly increased crop yields.

Precision management practices that combine different management components into high yield and high efficiency crop management systems are urgently needed. Taking rice (Oryza sativa L.) as an example, this study was conducted to develop a set of agrotechniques to improve rice productivity.

Rice is the staple food for more than 3 billion people in the world, making it the most important food crop for human consumption and food security (Cantrell and Teeves, 2002). To meet the consumption needs of the growing population, global average rice yield needs to be increased by $12 \%$ over the yield level of 2005 by 2015 (Normile, 2008). Asia harvests about $90 \%$ of the world's rice, however, Asia has not seen any rice yield increase in the past decade (Normile, 2008). Large yield gaps (2-5 $\mathrm{t} \mathrm{ha}^{-1}$ ) have been found in four Southeast Asian countries (Laborte et al., 2012). Unsuitable rates as well as wrong timing of nutrients application have resulted in very low nutrient use efficiency for rice (Peng et al., 2010).

Another great challenge for rice farming is water scarcity. Irrigated rice accounts for about $80 \%$ of the total fresh water resources used for irrigation in Asia, but the current water use efficiency for rice is about two times smaller than wheat (Bouman et al., 2007). Further, due to urbanization there is no scope to increase the rice growing area so, need to intensify the crop in the available rice growing area. Keeping above facts in mind, the study was conducted with the objective to study the effect of precision management practices on agronomic efficiency, water productivity, grain yield and economics of drip irrigated aerobic rice.

\section{Materials and Methods}

A field experiment was conducted at Zonal Agricultural Research Station, University of Agricultural Sciences, Bengaluru during summer 2016 and kharif 2016. The site is located at $13^{\circ} 05^{\prime} 21^{\prime \prime} \mathrm{N}$ latitude and $77^{\circ} 34^{\prime}$ $02 "$ E longitude with an altitude of $947 \mathrm{~m}$ above mean sea level. The soil of the experimental site was sandy loam. The initial soil $\mathrm{pH}$ was 5.93 and electrical conductivity was $0.34 \mathrm{dSm}^{-1}$. Available nitrogen, phosphorus and potassium were 319.3, 28.4 and $293.0 \mathrm{~kg} \mathrm{ha}{ }^{-1}$, respectively. The experiment was laid out in Randomized Complete Block Design with factorial concept (FRCBD) and replicated thrice.

Two nutrient management practices $\left(\mathrm{N}_{1}: 50 \%\right.$ $\mathrm{N} \& \mathrm{~K}$ from sowing to $30 \mathrm{DAS}+25 \% \mathrm{~N} \& \mathrm{~K}$ from 31 to $50 \mathrm{DAS}+25 \% \mathrm{~N} \& \mathrm{~K}$ from 51 to 80 DAS and $\mathrm{N}_{2}: 25 \% \mathrm{~N} \& \mathrm{~K}$ from sowing to 30 DAS $+25 \%$ N\&K from 31 to 50 DAS $+25 \%$ $\mathrm{N} \& \mathrm{~K}$ from 51 to $80 \mathrm{DAS}+25 \% \mathrm{~N} \& \mathrm{~K}$ from 81 to $105 \mathrm{DAS})$, three planting geometry $\left(\mathrm{P}_{1}\right.$ : $25 \times 25 \mathrm{~cm}, \mathrm{P}_{2}: 25 \times 20 \mathrm{~cm}$ and $\left.\mathrm{P}_{3}: 25 \times 15 \mathrm{~cm}\right)$ and two water management practices $\left(\mathrm{I}_{1}\right.$ : Drip irrigation at $125 \% \mathrm{PE}$ up to tillering $+150 \%$ $\mathrm{PE}$ from tillering to PI $+200 \% \mathrm{PE}$ from PI to physiological maturity and $\mathrm{I}_{2}$ : Drip irrigation at $100 \% \mathrm{PE}$ up to tillering $+125 \% \mathrm{PE}$ from tillering to $\mathrm{PI}+150 \% \mathrm{PE}$ from $\mathrm{PI}$ to physiological maturity) with one control (Recommended plant population and soil application of fertilizer dose with drip irrigation) and one absolute control (no RDF and drip irrigation) were included in this study. 
The land was brought to fine tilth before sowing by ploughing twice with tractor drawn disc plough and passing cultivator and two harrowing. Seeds of MAS 946-1 rice variety were dibbled at 2 per hill by following spacing of $25 \mathrm{~cm} \times 25 \mathrm{~cm}, 25 \mathrm{~cm} \times 20 \mathrm{~cm}$ and $25 \mathrm{~cm} \times 15 \mathrm{~cm}$ as per the treatment with seed rate of $5 \mathrm{~kg} \mathrm{ha}^{-1}$. FYM at 10 tonnes $\mathrm{ha}^{-1}$ was applied two weeks before sowing. Nutrients were applied through fertigation, drip fertigation system included pump, filter units, fertigation tank, ventury, main line and sub line. The required fertilizer nutrients were calculated and were applied as per treatments whereas phosphorous was applied in two equal splits (50 per cent as basal and remaining 50 per cent at 30 DAS) uniform to all the treatments. The recommended dose of fertilizer was 125:62.5:62.5 $\mathrm{kg} \mathrm{N}, \mathrm{P}_{2} \mathrm{O}_{5}$ and $\mathrm{K}_{2} \mathrm{O}$ ha $^{-1}$ during summer 2016 and 100:50:50 $\mathrm{kg} \mathrm{N}, \mathrm{P}_{2} \mathrm{O}_{5}$ and $\mathrm{K}_{2} \mathrm{O}$ ha ${ }^{-1}$ during kharif 2016. Pre-sowing irrigation was uniformly given to all treatments. Irrigation was provided through laterals separated at $50 \mathrm{~cm}$ apart in alternative rows. Inline emitters were at 40 $\mathrm{cm}$ apart with discharge rate of $3 \mathrm{lph}$. According to treatments drip irrigation was scheduled every day based on pan evaporation (Epan) and the quantity of water was calculated as follows;

Volume $\left(1 \mathrm{ha}^{-1}\right)=\operatorname{Epan} \times \mathrm{Kp} \times$ Area $\left(\mathrm{m}^{2}\right)$

Where,

Epan $=$ Pan evaporation

$\mathrm{K}_{\mathrm{p}}=$ Pan factor $(0.80)$

Time of operation of drip system to deliver the required volume of water per plot was computed based on the formula;

Time of

$$
\text { Volume of water required }\left(1 \text { plot }^{-1}\right)
$$

Application (hr) $=$

Emitter dicharge $(\mathrm{lph}) \times$ No. of emitters plot $^{-1}$
For control and absolute control drip irrigation was scheduled at 150 per cent pan evaporation throughout all the growth stages. As per treatment requirement fertigation was provided and the fertigation was scheduled at once in four days. Nitrogen and potassium were supplied through urea $(46 \% \mathrm{~N})$ and sulphate of potash $\left(50 \% \mathrm{~K}_{2} \mathrm{O}\right)$. However for control, muriate of potash used as potassium source and SSP as phosphorus source (for all the treatments). Londax power (Bensulfuron methyl $0.6 \%$ + Pretilachlor $6 \%$ GR) at $10 \mathrm{~kg}$ $\mathrm{ha}^{-1}$ was applied at 2 DAS as pre-emergence herbicide. Plant population was maintained according to the treatment by thinning excess seedlings at 21 DAS leaving one seedling per hill. Healthy crop stand was ensured by adopting need based plant protection and recommended package of practices. The Agronomic efficiency of nitrogen, phosphorus and potassium was calculated by using the formula:

(Grain yield in treatment plot - Grain yield in $\operatorname{AE}\left(\mathrm{kg} \mathrm{kg}^{-1}\right)=\frac{\text { absolute control plot })\left(\mathrm{kg} \mathrm{ha}^{-1}\right)}{\text { Nutrient applied }\left(\mathrm{kg} \mathrm{ha}^{-1}\right)}$

The quantity of water used by each treatment was calculated based on effective rainfall and open pan evaporation. The WUE was calculated by using following formula:

Wrain yield $\left(\mathrm{kg} \mathrm{ha}^{-1}\right)$
Quantity of total water applied $(\mathrm{cm})$

The cost of various inputs used and the prices of outputs in the prevailing local markets were considered for cost of cultivation, gross returns and net returns per hectare.

Net returns were calculated by deducting the cost of cultivation from total gross returns. Benefit-cost ratio was worked as fallows, 

Gross returns (Rs. ha ${ }^{-1}$ )
B: $\mathrm{C}$ ratio =

All the data were analyzed and the results are presented and discussed at a probability level of 5 per cent.

\section{Results and Discussion}

\section{Agronomic efficiency}

Application of $25 \% \mathrm{~N} \& \mathrm{~K}$ from sowing to 30 $\mathrm{DAS}+25 \% \mathrm{~N} \& \mathrm{~K}$ from 31 to $50 \mathrm{DAS}+$ $25 \% \mathrm{~N} \& \mathrm{~K}$ from 51 to $80 \mathrm{DAS}+25 \% \mathrm{~N} \&$ $\mathrm{K}$ from 81 to $105 \mathrm{DAS}$ recorded significantly higher agronomic efficiency of nitrogen, phosphorus and potassium in pooled data (50.85, 104.60 and $101.70 \mathrm{~kg} \mathrm{~kg}^{-1}$, respectively) and resembling trend in first (49.40, 98.80 and $98.80 \mathrm{~kg} \mathrm{~kg}^{-1}$, respectively) and second season (52.30, 104.60 and 104.60 $\mathrm{kg} \mathrm{kg}^{-1}$, respectively). Significantly lower agronomic efficiency of nitrogen, phosphorus and potassium by aerobic rice were noticed in application of $50 \% \mathrm{~N} \& \mathrm{~K}$ from sowing to 30 $\mathrm{DAS}+25 \% \mathrm{~N} \& \mathrm{~K}$ from 31 to $50 \mathrm{DAS}+$ $25 \% \mathrm{~N} \& \mathrm{~K}$ from 51 to $80 \mathrm{DAS}(26.77,53.55$ and $53.55 \mathrm{~kg} \mathrm{~kg}^{-1}$, respectively). Agronomic efficiency of nitrogen, phosphorus and potassium also varied significantly due to different planting geometry. Pooled analysis indicated, significantly higher agronomic efficiency of nitrogen, phosphorus and potassium were observed (46.91, 93.83 and $93.83 \mathrm{~kg} \mathrm{~kg}^{-1}$, respectively) in planting geometry of $25 \times 15 \mathrm{~cm}$ and similar trend in first (45.38, 90.77 and $90.77 \mathrm{~kg} \mathrm{~kg}{ }^{-1}$, respectively) and second season $(48.44,96.88$ and $96.88 \mathrm{~kg} \mathrm{~kg}^{-1}$, respectively). Planting geometry of $25 \times 25 \mathrm{~cm}$ recorded significantly lower agronomic efficiency of nitrogen, phosphorus and potassium (30.84, 61.68 and $61.68 \mathrm{~kg} \mathrm{~kg}^{-1}$, respectively). Drip irrigation scheduling at $125 \%$ PE up to tillering $+150 \%$ $\mathrm{PE}$ from tillering to PI $+200 \% \mathrm{PE}$ from PI to physiological maturity recorded significantly higher agronomic efficiency of nitrogen, phosphorus and potassium in pooled data (41.25, 82.49 and $82.49 \mathrm{~kg} \mathrm{~kg}^{-1}$, respectively) and identical trend in first (39.34, 78.68 and $78.68 \mathrm{~kg} \mathrm{~kg}^{-1}$, respectively) and second season $\left(43.15,86.31\right.$ and $86.31 \mathrm{~kg} \mathrm{~kg}^{-1}$, respectively). Significantly lower agronomic efficiency of nitrogen, phosphorus and potassium of aerobic rice were noticed in scheduling of drip irrigation at $100 \% \mathrm{PE}$ up to tillering $+125 \% \mathrm{PE}$ from tillering to $\mathrm{PI}+$ $150 \%$ PE from PI to physiological maturity (36.38, 72.75 and $72.75 \mathrm{~kg} \mathrm{~kg}^{-1}$, respectively). Interaction between nutrient management $x$ planting geometry $\times$ water management significantly influenced agronomic efficiency of nitrogen, phosphorus and potassium.

Application of $25 \% \mathrm{~N} \& \mathrm{~K}$ from sowing to 30 $\mathrm{DAS}+25 \% \mathrm{~N} \& \mathrm{~K}$ from 31 to $50 \mathrm{DAS}+$ $25 \% \mathrm{~N} \& \mathrm{~K}$ from 51 to $80 \mathrm{DAS}+25 \% \mathrm{~N} \&$ $\mathrm{K}$ from 81 to 105 DAS with planting geometry of $25 \times 15 \mathrm{~cm}$ with drip irrigation scheduling at $125 \%$ PE up to tillering $+150 \%$ $\mathrm{PE}$ from tillering to PI $+200 \% \mathrm{PE}$ from PI to physiological maturity recorded higher agronomic efficiency of nitrogen, phosphorus and potassium in pooled analysis (62.87, 125.74 and $125.74 \mathrm{~kg} \mathrm{~kg}^{-1}$, respectively) first

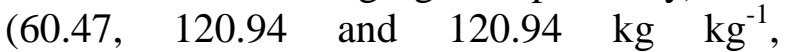
respectively) and second season (65.27, 130.54 and $130.54 \mathrm{~kg} \mathrm{~kg}^{-1}$, respectively). However, lower agronomic efficiency of nitrogen, phosphorus and potassium were noted in control $(15.31,30.62$ and $30.62 \mathrm{~kg}$ $\mathrm{kg}^{-1}$, respectively) receiving soil application of fertilizers with drip irrigation (Table 1).

Higher agronomic efficiency of nitrogen, phosphorus and potassium under application of $\mathrm{N}$ and $\mathrm{K}$ in four equal splits up to 105 DAS, planting geometry of $25 \times 15 \mathrm{~cm}$ and drip irrigation scheduling at $125 \% \mathrm{PE}$ up to tillering $+150 \%$ PE from tillering to PI + $200 \%$ PE from PI to physiological maturity 
due to higher grain yield compared to other treatments. Drip fertigation scheduling at favourable moisture regimes in general registered higher nutrient use efficiency $(\mathrm{N}, \mathrm{P}$ and $\mathrm{K}$ ) as compared to direct soil application of nutrients. This was attributed to better availability of moisture and nutrients throughout crop growth stages in drip fertigation system leading to better uptake of nutrients, production of higher dry matter and in turn economical yield besides reduced loss of nutrients through leaching especially $\mathrm{N}$ and $\mathrm{K}$. This indicated that required water availability in right amount at right time resulted in improved nutrient uptake with lesser losses. Such findings are in consonance with the findings of Raina et al., (2011) in apricot and Anusha (2015) in drip irrigated aerobic rice. In these studies higher use efficiency of nutrients under fertigation might be ascribed to increased availability to the plants directly near the root zone. Lower nutrient use efficiency in soil application of fertilizers might be due to reduced nutrient uptake associated with reduced moisture availability and less solubility of nutrients. These results are in conformity with Gururaj (2013) and Anusha (2015).

\section{Grain yield}

The grain yield of aerobic rice was significantly influenced by precision management practices. Application of $25 \% \mathrm{~N}$ $\& \mathrm{~K}$ from sowing to $30 \mathrm{DAS}+25 \% \mathrm{~N} \& \mathrm{~K}$ from 31 to $50 \mathrm{DAS}+25 \% \mathrm{~N} \& \mathrm{~K}$ from 51 to $80 \mathrm{DAS}+25 \% \mathrm{~N} \& \mathrm{~K}$ from 81 to $105 \mathrm{DAS}$ recorded significantly higher grain yield in pooled analysis (7.36 $\left.\mathrm{t} \mathrm{ha}^{-1}\right)$ and identical trend in first $\left(7.57 \mathrm{t} \mathrm{ha}^{-1}\right)$ and second season (7.15 $\left.\mathrm{t} \mathrm{ha}^{-1}\right)$. whereas, application of $50 \% \mathrm{~N} \&$ $\mathrm{K}$ from sowing to $30 \mathrm{DAS}+25 \% \mathrm{~N} \& \mathrm{~K}$ from 31 to $50 \mathrm{DAS}+25 \% \mathrm{~N} \& \mathrm{~K}$ from 51 to 80 DAS recorded significantly lower grain yield $\left(4.95 \mathrm{t} \mathrm{ha}^{-1}\right)$. Planting geometry of $25 \times 15 \mathrm{~cm}$ recorded higher grain yield in pooled analysis $\left(6.97 \mathrm{t} \mathrm{ha}^{-1}\right)$ and similar trend in first $\left(7.17 \mathrm{t} \mathrm{ha}^{-1}\right)$ and second season $(6.76 \mathrm{t}$ $\left.\mathrm{ha}^{-1}\right)$.

Significantly lower grain yield $\left(5.36 \mathrm{t} \mathrm{ha}^{-1}\right)$ was registered in planting geometry of $25 \times 25$ $\mathrm{cm}$ in pooled analysis. Drip irrigation scheduling at $125 \%$ PE up to tillering $+150 \%$ PE from tillering to PI $+200 \%$ PE from PI to physiological maturity noticed higher grain yield in pooled analysis (6.40 $\left.\mathrm{t} \mathrm{ha}^{-1}\right)$ and identical trend was also followed in first $(6.56$ $\mathrm{t} \mathrm{ha}^{-1}$ ) and second season (6.23 $\left.\mathrm{t} \mathrm{ha}^{-1}\right)$. Whereas, lower grain yield $\left(5.91 \mathrm{t} \mathrm{ha}^{-1}\right)$ was observed in scheduling of drip irrigation at $100 \% \mathrm{PE}$ up to tillering $+125 \% \mathrm{PE}$ from tillering to $\mathrm{PI}+150 \% \mathrm{PE}$ from $\mathrm{PI}$ to physiological maturity.

Interaction effect of nutrient management $x$ planting geometry $\times$ water management found to be significant and the application of $25 \% \mathrm{~N}$ $\& \mathrm{~K}$ from sowing to $30 \mathrm{DAS}+25 \% \mathrm{~N} \& \mathrm{~K}$ from 31 to $50 \mathrm{DAS}+25 \% \mathrm{~N} \& \mathrm{~K}$ from 51 to $80 \mathrm{DAS}+25 \% \mathrm{~N} \& \mathrm{~K}$ from 81 to $105 \mathrm{DAS}$ with planting geometry of $25 \times 15 \mathrm{~cm}$ with drip irrigation scheduling at $125 \% \mathrm{PE}$ up to tillering $+150 \% \mathrm{PE}$ from tillering to $\mathrm{PI}+$ $200 \%$ PE from PI to physiological maturity achieved higher grain yield in pooled analysis $\left(8.56 \mathrm{t} \mathrm{ha}^{-1}\right)$ and the same trend in first $(8.68 \mathrm{t}$ $\left.\mathrm{ha}^{-1}\right)$ and second $\left(8.45 \mathrm{t} \mathrm{ha}^{-1}\right)$ season. Where, the lower grain yield (3.81 and $2.27 \mathrm{t} \mathrm{ha}^{-1}$, respectively) was recorded in soil application of fertilizers with drip irrigation (control) and absolute control, respectively among all the precision management practices (Table 1).

The yield of aerobic rice differed significantly due to difference in growth attributes which were ultimately affected by time and levels of nutrients applied. Since the economic yield is a part of total biological yield of season, accumulation of total dry matter helps in enhancement of economical yield of a season. 
Table.1 Agronomic efficiency $\left(\mathrm{kg} \mathrm{kg}^{-1}\right)$ as influenced by precision management practices in drip irrigated aerobic rice

\begin{tabular}{|c|c|c|c|c|c|c|c|c|c|c|c|c|}
\hline \multirow[t]{2}{*}{ Treatments } & \multicolumn{3}{|c|}{ Agronomic efficiency of nitrogen } & \multicolumn{3}{|c|}{$\begin{array}{c}\begin{array}{c}\text { Agronomic efficiency of } \\
\text { phosphorus }\end{array} \\
\end{array}$} & \multicolumn{3}{|c|}{$\begin{array}{c}\text { Agronomic efficiency of } \\
\text { potassium }\end{array}$} & \multicolumn{3}{|c|}{$\begin{array}{c}\text { Grain yield } \\
\left(\mathrm{t} \mathrm{ha}^{-1}\right)\end{array}$} \\
\hline & $\begin{array}{c}\text { Summer } \\
2016\end{array}$ & $\begin{array}{c}\text { Kharif } \\
2016\end{array}$ & Pooled & $\begin{array}{c}\text { Summer } \\
2016\end{array}$ & $\begin{array}{c}\text { Kharif } \\
2016\end{array}$ & Pooled & $\begin{array}{c}\text { Summer } \\
2016\end{array}$ & $\begin{array}{c}\text { Kharif } \\
2016\end{array}$ & Pooled & $\begin{array}{c}\text { Summer } \\
2016\end{array}$ & $\begin{array}{c}\text { Kharif } \\
2016\end{array}$ & Pooled \\
\hline \multicolumn{13}{|c|}{ Nutrient management $(\mathbf{N})$} \\
\hline $\mathrm{N}_{1}$ & 25.08 & 28.46 & 26.77 & 50.17 & 56.93 & 53.55 & 50.17 & 56.93 & 53.55 & 5.14 & 4.76 & 4.95 \\
\hline $\mathbf{N}_{2}$ & 49.40 & 52.30 & 50.85 & 98.80 & 104.60 & 101.70 & 98.80 & 104.60 & 101.70 & 7.57 & 7.15 & 7.36 \\
\hline S. Em. \pm & 0.79 & 1.80 & 1.02 & 1.57 & 3.60 & 2.04 & 1.57 & 3.60 & 2.04 & 0.08 & 0.18 & 0.09 \\
\hline C.D.@5\% & 2.28 & 5.23 & 2.88 & 4.57 & 10.46 & 5.77 & 4.57 & 10.46 & 5.77 & 0.22 & 0.51 & 0.24 \\
\hline \multicolumn{13}{|c|}{ Planting geometry (P) } \\
\hline $\mathbf{P}_{1}$ & 29.11 & 32.57 & 30.84 & 58.22 & 65.13 & 61.68 & 58.22 & 65.13 & 61.68 & 5.54 & 5.18 & 5.36 \\
\hline $\mathbf{P}_{2}$ & 37.23 & 40.13 & 38.68 & 74.47 & 80.27 & 77.37 & 74.47 & 80.27 & 77.37 & 6.35 & 5.93 & 6.14 \\
\hline $\mathbf{P}_{3}$ & 45.38 & 48.44 & 46.91 & 90.77 & 96.88 & 93.83 & 90.77 & 96.88 & 93.83 & 7.17 & 6.76 & 6.97 \\
\hline S. Em \pm & 0.96 & 2.20 & 1.25 & 1.92 & 4.41 & 2.50 & 1.92 & 4.41 & 2.50 & 0.09 & 0.22 & 0.10 \\
\hline C.D.@5\% & 2.80 & 6.40 & 3.53 & 5.60 & 12.81 & 7.06 & 5.60 & 12.81 & 7.06 & 0.27 & 0.63 & 0.29 \\
\hline \multicolumn{13}{|c|}{ Water management (I) } \\
\hline$I_{1}$ & 39.34 & 43.15 & 41.25 & 78.68 & 86.31 & 82.49 & 78.68 & 86.31 & 82.49 & 6.56 & 6.23 & 6.40 \\
\hline $\mathbf{I}_{2}$ & 35.14 & 37.61 & 36.38 & 70.29 & 75.22 & 72.75 & 70.29 & 75.22 & 72.75 & 6.14 & 5.68 & 5.91 \\
\hline S. Em \pm & 0.79 & 1.80 & 1.02 & 1.57 & 3.60 & 2.04 & 1.57 & 3.60 & 2.04 & 0.08 & 0.18 & 0.09 \\
\hline C.D.@5\% & 2.28 & 5.23 & 2.88 & 4.57 & 10.46 & 5.77 & 4.57 & 10.46 & 5.77 & 0.22 & 0.51 & 0.24 \\
\hline \multicolumn{13}{|c|}{ Nutrient management $x$ planting geometry $x$ water management ( $\begin{array}{l}\text { N x } \\
\end{array}$ x I) } \\
\hline $\mathbf{N}_{1} \mathbf{P}_{1} \mathbf{I}_{1}$ & 19.43 & 25.38 & 22.41 & 38.87 & 50.77 & 44.82 & 38.87 & 50.77 & 44.82 & 4.57 & 4.46 & 4.52 \\
\hline $\mathbf{N}_{1} \mathbf{P}_{1} \mathbf{I}_{2}$ & 15.70 & 19.25 & 17.48 & 31.40 & 38.50 & 34.95 & 31.40 & 38.50 & 34.95 & 4.20 & 3.84 & 4.02 \\
\hline $\mathbf{N}_{1} \mathbf{P}_{2} \mathbf{I}_{1}$ & 27.50 & 29.88 & 28.69 & 55.00 & 59.77 & 57.38 & 55.00 & 59.77 & 57.38 & 5.38 & 4.91 & 5.14 \\
\hline $\mathbf{N}_{1} \mathbf{P}_{2} \mathbf{I}_{2}$ & 22.57 & 26.72 & 24.64 & 45.13 & 53.43 & 49.28 & 45.13 & 53.43 & 49.28 & 4.89 & 4.59 & 4.74 \\
\hline $\mathbf{N}_{1} \mathbf{P}_{3} \mathbf{I}_{1}$ & 34.37 & 37.66 & 36.01 & 68.73 & 75.33 & 72.03 & 68.73 & 75.33 & 72.03 & 6.07 & 5.68 & 5.88 \\
\hline $\mathbf{N}_{1} \mathbf{P}_{3} \mathbf{I}_{2}$ & 30.93 & 31.89 & 31.41 & 61.87 & 63.77 & 62.82 & 61.87 & 63.77 & 62.82 & 5.72 & 5.11 & 5.42 \\
\hline $\mathbf{N}_{2} \mathbf{P}_{1} \mathbf{I}_{1}$ & 42.87 & 45.57 & 44.22 & 85.73 & 91.14 & 88.44 & 85.73 & 91.14 & 88.44 & 6.92 & 6.48 & 6.70 \\
\hline $\mathbf{N}_{2} \mathbf{P}_{1} \mathbf{I}_{2}$ & 38.43 & 40.06 & 39.25 & 76.87 & 80.13 & 78.50 & 76.87 & 80.13 & 78.50 & 6.47 & 5.92 & 6.20 \\
\hline $\mathbf{N}_{2} \mathbf{P}_{2} \mathbf{I}_{1}$ & 51.40 & 55.15 & 53.28 & 102.80 & 110.30 & 106.55 & 102.80 & 110.30 & 106.55 & 7.77 & 7.43 & 7.60 \\
\hline $\mathbf{N}_{2} \mathbf{P}_{2} \mathbf{I}_{2}$ & 47.47 & 48.79 & 48.13 & 94.93 & 97.58 & 96.25 & 94.93 & 97.58 & 96.25 & 7.38 & 6.80 & 7.09 \\
\hline $\mathbf{N}_{\mathbf{2}} \mathbf{P}_{3} \mathbf{I}_{1}$ & 60.47 & 65.27 & 62.87 & 120.94 & 130.54 & 125.74 & 120.94 & 130.54 & 125.74 & 8.68 & 8.45 & 8.56 \\
\hline $\mathbf{N}_{2} \mathbf{P}_{3} \mathbf{I}_{2}$ & 55.77 & 58.95 & 57.36 & 111.53 & 117.90 & 114.72 & 111.53 & 117.90 & 114.72 & 8.21 & 7.81 & 8.01 \\
\hline Control & 12.90 & 17.72 & 15.31 & 25.80 & 35.43 & 30.62 & 25.80 & 35.43 & 30.62 & 3.92 & 3.69 & 3.81 \\
\hline Ab. control & 0.00 & 0.00 & 0.00 & 0.00 & 0.00 & 0.00 & 0.00 & 0.00 & 0.00 & 2.63 & 1.92 & 2.27 \\
\hline S. $\mathbf{E m} \pm$ & 1.92 & 4.41 & 2.50 & 3.85 & 8.81 & 5.01 & 3.85 & 8.81 & 5.01 & 0.18 & 0.43 & 0.21 \\
\hline C.D.@5\% & 5.59 & 12.80 & 7.06 & 11.19 & 25.61 & 14.12 & 11.19 & 25.61 & 14.12 & 0.53 & 1.25 & 0.59 \\
\hline
\end{tabular}

Note: CD-Critical difference, NS-Non significant

$\mathrm{N}_{1}: 50 \% \mathrm{~N} \& \mathrm{~K}$ from sowing to $30 \mathrm{DAS}+25 \% \mathrm{~N} \& \mathrm{~K}$ from 31 to $50 \mathrm{DAS}+25 \% \mathrm{~N} \& \mathrm{~K}$ from 51 to $80 \mathrm{DAS}, \mathrm{N}_{2}: 25 \% \mathrm{~N} \& \mathrm{~K}$ from sowing to $30 \mathrm{DAS}+25 \% \mathrm{~N} \& \mathrm{~K}$ from 31 to $50 \mathrm{DAS}+25 \% \mathrm{~N} \& \mathrm{~K}$ from 51 to $80 \mathrm{DAS}+25 \% \mathrm{~N} \& \mathrm{~K}$ from 81 to $105 \mathrm{DAS}, \mathrm{P}_{1}: 25 \times 25 \mathrm{~cm}, \mathrm{P}_{2}: 25 \times 20 \mathrm{~cm}, \mathrm{P}_{3}: 25 \times 15 \mathrm{~cm}, \mathrm{I}_{1}$ : Drip irrigation at $125 \% \mathrm{PE}$ up to tillering $+150 \% \mathrm{PE}$ from tillering to PI+200\% PE from PI to physiological maturity, $\mathrm{I}_{2}$ : Drip irrigation at $100 \% \mathrm{PE}$ up to tillering+125\% PE from tillering to PI+150\% PE from PI to physiological maturity, Control: (Drip irrigation at $150 \%$ PE throughout all growth stages and soil application of fertilizers), Ab. Control = Absolute Control: (No RDF with drip irrigation) 
Table.2 Water used and water use efficiency as influenced by precision management practices in drip irrigated aerobic rice

\begin{tabular}{|c|c|c|c|c|c|c|}
\hline \multirow[t]{2}{*}{ Treatments } & \multicolumn{3}{|c|}{ Water used $(\mathrm{cm})$} & \multicolumn{3}{|c|}{ Water use efficiency $\left(\mathrm{kg} \mathrm{ha}^{\left.-\mathrm{cm}^{-1}\right)}\right.$} \\
\hline & Summer 2016 & Kharif 2016 & Pooled & $\begin{array}{c}\text { Summer } \\
2016\end{array}$ & $\begin{array}{c}\text { Kharif } \\
2016\end{array}$ & Pooled \\
\hline $\mathbf{T}_{1}-\mathbf{N}_{1} \mathbf{P}_{1} \mathbf{I}_{1}$ & 128.15 & 104.50 & 116.32 & 35.7 & 42.7 & 38.8 \\
\hline $\mathbf{T}_{2}-\mathbf{N}_{1} \mathbf{P}_{1} \mathbf{I}_{2}$ & 107.00 & 83.84 & 95.42 & 39.3 & 45.8 & 42.2 \\
\hline $\mathbf{T}_{3}-\mathbf{N}_{1} \mathbf{P}_{2} \mathbf{I}_{1}$ & 128.15 & 104.50 & 116.32 & 42.0 & 47.0 & 44.2 \\
\hline $\mathbf{T}_{4}-\mathbf{N}_{1} \mathbf{P}_{2} \mathbf{I}_{2}$ & 107.00 & 83.84 & 95.42 & 45.7 & 54.7 & 49.7 \\
\hline $\mathbf{T}_{5}-\mathbf{N}_{1} \mathbf{P}_{3} \mathbf{I}_{1}$ & 128.15 & 104.50 & 116.32 & 47.3 & 54.4 & 50.5 \\
\hline $\mathbf{T}_{6}-\mathbf{N}_{1} \mathbf{P}_{3} \mathbf{I}_{2}$ & 107.00 & 83.84 & 95.42 & 53.5 & 60.9 & 56.7 \\
\hline $\mathbf{T}_{7}-\mathbf{N}_{2} \mathbf{P}_{1} \mathbf{I}_{1}$ & 128.15 & 104.50 & 116.32 & 54.0 & 62.0 & 57.6 \\
\hline $\mathbf{T}_{8}-\mathbf{N}_{2} \mathbf{P}_{1} \mathbf{I}_{2}$ & 107.00 & 83.84 & 95.42 & 60.5 & 70.7 & 65.0 \\
\hline $\mathbf{T}_{9}-\mathbf{N}_{2} \mathbf{P}_{2} \mathbf{I}_{1}$ & 128.15 & 104.50 & 116.32 & 60.6 & 71.1 & 65.4 \\
\hline $\mathbf{T}_{10}-\mathbf{N}_{2} \mathbf{P}_{2} \mathbf{I}_{2}$ & 107.00 & 83.84 & 95.42 & 68.9 & 81.1 & 74.3 \\
\hline $\mathbf{T}_{11}-\mathbf{N}_{2} \mathbf{P}_{3} \mathbf{I}_{1}$ & 128.15 & 104.50 & 116.32 & 67.7 & 80.8 & 73.6 \\
\hline $\mathbf{T}_{12}-\mathbf{N}_{2} \mathbf{P}_{3} \mathbf{I}_{2}$ & 107.00 & 83.84 & 95.42 & 76.7 & 93.2 & 83.9 \\
\hline $\mathbf{T}_{13}$-Control & 130.51 & 96.25 & 113.38 & 30.0 & 38.3 & 33.6 \\
\hline $\mathrm{T}_{14}$-Absolute control & 130.51 & 96.25 & 113.38 & 20.2 & 19.9 & 20.1 \\
\hline
\end{tabular}

Note: CD-Critical difference, NS-Non significant

$\mathrm{N}_{1}: 50 \% \mathrm{~N} \& \mathrm{~K}$ from sowing to $30 \mathrm{DAS}+25 \% \mathrm{~N} \& \mathrm{~K}$ from 31 to $50 \mathrm{DAS}+25 \% \mathrm{~N} \& \mathrm{~K}$ from 51 to $80 \mathrm{DAS}, \mathrm{N}_{2}: 25 \% \mathrm{~N} \& \mathrm{~K}$ from sowing to $30 \mathrm{DAS}+25 \% \mathrm{~N} \& \mathrm{~K}$ from 31 to $50 \mathrm{DAS}+25 \% \mathrm{~N} \& \mathrm{~K}$ from 51 to $80 \mathrm{DAS}+25 \% \mathrm{~N} \& \mathrm{~K}$ from 81 to $105 \mathrm{DAS}, \mathrm{P}_{1}: 25 \times 25 \mathrm{~cm}, \mathrm{P}_{2}: 25 \times 20 \mathrm{~cm}, \mathrm{P}_{3}: 25 \times 15 \mathrm{~cm}, \mathrm{I}_{1}:$ Drip irrigation at $125 \%$ PE up to tillering $+150 \% \mathrm{PE}$ from tillering to PI+200\% PE from PI to physiological maturity, $\mathrm{I}_{2}$ : Drip irrigation at $100 \% \mathrm{PE}$ up to tillering+125\% PE from tillering to PI+150\% PE from PI to physiological maturity, Control: (Drip irrigation at $150 \%$ PE throughout all growth stages and soil application of fertilizers), Ab. Control = Absolute Control: (No RDF with drip irrigation) 
Table.3 Economics as influenced by precision management practices in drip irrigated aerobic rice

\begin{tabular}{|c|c|c|c|c|c|c|c|c|c|c|c|c|}
\hline \multirow[t]{2}{*}{ Treatments } & \multicolumn{3}{|c|}{ Cost of cultivation ( $\square$ ha $^{-1}$ ) } & \multicolumn{3}{|c|}{ Gross returns ( $\square$ ha $^{-1}$ ) } & \multicolumn{3}{|c|}{ Net returns $\left(\square \mathrm{ha}^{-1}\right)$} & \multicolumn{3}{|c|}{ B:C ratio } \\
\hline & $\begin{array}{c}\text { Summer } \\
2016\end{array}$ & $\begin{array}{c}\text { Kharif } \\
2016\end{array}$ & Pooled & $\begin{array}{c}\text { Summer } \\
2016\end{array}$ & $\begin{array}{c}\text { Kharif } \\
2016\end{array}$ & Pooled & $\begin{array}{c}\text { Summer } \\
2016\end{array}$ & $\begin{array}{c}\text { Kharif } \\
2016\end{array}$ & Pooled & $\begin{array}{c}\text { Summer } \\
2016\end{array}$ & $\begin{array}{c}\text { Kharif } \\
2016\end{array}$ & Pooled \\
\hline $\mathbf{N}_{1} \mathbf{P}_{1} \mathbf{I}_{1}$ & 57473 & 54878 & 56175 & 74352 & 72374 & 73363 & 16879 & 17496 & 17188 & 1.29 & 1.32 & 1.31 \\
\hline $\mathbf{N}_{1} \mathbf{P}_{1} \mathbf{I}_{2}$ & 57313 & 54718 & 56015 & 68313 & 62771 & 65542 & 11000 & 8053 & 9527 & 1.19 & 1.15 & 1.17 \\
\hline $\mathbf{N}_{1} \mathbf{P}_{2} \mathbf{I}_{1}$ & 57491 & 54896 & 56193 & 87507 & 80215 & 83861 & 30016 & 25319 & 27668 & 1.52 & 1.46 & 1.49 \\
\hline $\mathbf{N}_{1} \mathbf{P}_{2} \mathbf{I}_{2}$ & 57331 & 54736 & 56033 & 79482 & 74806 & 77144 & 22151 & 20070 & 21110 & 1.39 & 1.37 & 1.38 \\
\hline $\mathbf{N}_{1} \mathbf{P}_{3} \mathbf{I}_{1}$ & 57525 & 54930 & 56227 & 98645 & 92664 & 95654 & 41120 & 37734 & 39427 & 1.71 & 1.69 & 1.70 \\
\hline $\mathbf{N}_{1} \mathbf{P}_{3} \mathbf{I}_{2}$ & 57365 & 54770 & 56067 & 93059 & 83622 & 88340 & 35694 & 28852 & 32273 & 1.62 & 1.53 & 1.57 \\
\hline $\mathbf{N}_{2} \mathbf{P}_{1} \mathbf{I}_{1}$ & 57473 & 54878 & 56175 & 112456 & 105534 & 108995 & 54983 & 50657 & 52820 & 1.96 & 1.92 & 1.94 \\
\hline $\mathbf{N}_{2} \mathbf{P}_{1} \mathbf{I}_{2}$ & 57313 & 54718 & 56015 & 105172 & 96684 & 100928 & 47859 & 41966 & 44913 & 1.84 & 1.77 & 1.80 \\
\hline $\mathbf{N}_{2} \mathbf{P}_{2} \mathbf{I}_{1}$ & 57491 & 54896 & 56193 & 126182 & 120764 & 123473 & 68691 & 65868 & 67280 & 2.19 & 2.20 & 2.20 \\
\hline $\mathbf{N}_{2} \mathbf{P}_{2} \mathbf{I}_{2}$ & 57331 & 54736 & 56033 & 119822 & 110828 & 115325 & 62491 & 56093 & 59292 & 2.09 & 2.02 & 2.06 \\
\hline $\mathbf{N}_{2} \mathbf{P}_{3} \mathbf{I}_{1}$ & 57525 & 54930 & 56227 & 140953 & 137207 & 139080 & 83428 & 82277 & 82853 & 2.45 & 2.50 & 2.47 \\
\hline $\mathbf{N}_{2} \mathbf{P}_{3} \mathbf{I}_{2}$ & 57365 & 54770 & 56067 & 133306 & 127051 & 130179 & 75941 & 72282 & 74111 & 2.32 & 2.32 & 2.32 \\
\hline Control & 51291 & 49938 & 50615 & 63738 & 60140 & 61939 & 12446 & 10201 & 11324 & 1.24 & 1.20 & 1.22 \\
\hline Ab. control & 38915 & 38755 & 38835 & 42766 & 31618 & 37192 & 3851 & -7137 & -1643 & 1.10 & 0.82 & 0.96 \\
\hline
\end{tabular}

$\mathrm{N}_{1}: 50 \% \mathrm{~N} \& \mathrm{~K}$ from sowing to $30 \mathrm{DAS}+25 \% \mathrm{~N} \& \mathrm{~K}$ from 31 to $50 \mathrm{DAS}+25 \% \mathrm{~N} \& \mathrm{~K}$ from 51 to 80 DAS, $\mathrm{N}_{2}: 25 \% \mathrm{~N} \& \mathrm{~K}$ from sowing to $30 \mathrm{DAS}+25 \% \mathrm{~N} \& \mathrm{~K}$ from 31 to $50 \mathrm{DAS}+25 \% \mathrm{~N} \& \mathrm{~K}$ from 51 to $80 \mathrm{DAS}+25 \% \mathrm{~N} \& \mathrm{~K}$ from 81 to $105 \mathrm{DAS}, \mathrm{P}_{1}: 25 \times 25 \mathrm{~cm}, \mathrm{P}_{2}: 25 \times 20 \mathrm{~cm}, \mathrm{P}_{3}: 25 \times 15 \mathrm{~cm}, \mathrm{I}_{1}:$ Drip irrigation at $125 \%$ PE up to tillering+150\% PE from tillering to PI+200\% PE from PI to physiological maturity, $\mathrm{I}_{2}$ : Drip irrigation at $100 \%$ PE up to tillering+125\% PE from tillering to PI+150\% PE from PI to physiological maturity, Control: (Drip irrigation at 150\% PE throughout all growth stages and soil application of fertilizers), Ab. Control = Absolute Control: (No RDF with drip irrigation) 
Assessment of grain yield in different treatments indicated that significantly higher grain yield was observed with application of four equal splits of $\mathrm{N}$ and $\mathrm{K}$ up to $105 \mathrm{DAS}$ which was attributed to higher leaf area and total number of tillers resulting in higher dry matter production compared to $\mathrm{N}$ and $\mathrm{K}$ in 3 splits up to 80 DAS. Thus could be attributed due to the minimum loss of $\mathrm{N}$ and $\mathrm{K}$ through leaching and efficient $\mathrm{N}$-utilization by crop resulting in better vegetative growth and production of more filled spikelets, panicle weight and panicle length (Khavita and Balasubramanian, 2008). The straw and grain yields were significantly higher in $25 \mathrm{~cm}$ x 15 $\mathrm{cm}$. This might be due to cumulative influence of higher plant population, more leaf area index, more of light interception and higher number of effective tillers per meter square and higher total dry matter per meter square, resulting in increased grain yield. Similar results were in accordance with Sultana et al., (2012) and Ranjith (2015). Higher grain yield recorded with drip irrigation scheduling at $125 \% \mathrm{PE}$ up to tillering $+150 \%$ PE from tillering to PI + $200 \%$ PE from PI to physiological maturity in aerobic rice may be due to its superiority in producing higher productive tillers hill ${ }^{-1}$, panicle length, panicle weight, thousand grain weight and total number of grains panicle ${ }^{-1}$ with lower per cent chaffyness which is resulted in higher grain yield. The increase in the yield is related to higher leaf area index and crop growth rate which were contributed for assimilation of more photosynthates and resulted in superior yield attributes and yield. The similar type of results was also reported by Gururaj (2013). Due to frequent split application of fertilizers in drip irrigation coincided with the actual needs of season and favoured good growth, which resulted in maximum yield (Anusha, 2015). In this study also frequent application of fertilizers coincided with the nutrient demand and supplied more nutrients at peak time without any nutrient stress which might have resulted in higher grain yield than nutrients supplied through soil application.

\section{Total water used and water use efficiency (WUE)}

The variation was observed in total water used by aerobic rice due to drip irrigation scheduling based on open pan evaporation (Table 2). Aerobic rice with soil application of fertilizers and drip irrigation scheduling at $150 \%$ PE throughout all the growth stages used maximum water in first season (130.51 $\mathrm{cm})$. Whereas, in second season $(104.50 \mathrm{~cm})$ and pooled analysis $(116.32 \mathrm{~cm})$ scheduling of drip irrigation at $125 \% \mathrm{PE}$ up to tillering + $150 \%$ PE from tillering to PI $+200 \%$ PE from PI to physiological maturity used more water compared to scheduling of drip irrigation at $100 \% \mathrm{PE}$ up to tillering $+125 \% \mathrm{PE}$ from tillering to $\mathrm{PI}+150 \% \mathrm{PE}$ from $\mathrm{PI}$ to physiological maturity (107.0, 83.84 and $95.42 \mathrm{~cm}$ in first season, second season and pooled analysis, respectively). Water use efficiency (WUE) varied among precision management practices. Application of $25 \% \mathrm{~N}$ $\& \mathrm{~K}$ from sowing to $30 \mathrm{DAS}+25 \% \mathrm{~N} \& \mathrm{~K}$ from 31 to $50 \mathrm{DAS}+25 \% \mathrm{~N} \& \mathrm{~K}$ from 51 to $80 \mathrm{DAS}+25 \% \mathrm{~N} \& \mathrm{~K}$ from 81 to $105 \mathrm{DAS}$ with planting geometry of $25 \times 15 \mathrm{~cm}$ with drip irrigation scheduling at $100 \% \mathrm{PE}$ up to tillering $+125 \% \mathrm{PE}$ from tillering to PI + $150 \%$ PE from PI to physiological maturity recorded higher WUE $\left(83.9 \mathrm{~kg} \mathrm{ha}-\mathrm{cm}^{-1}\right)$ and similar trend in first $\left(76.7 \mathrm{~kg} \mathrm{ha}-\mathrm{cm}^{-1}\right)$ and second season $\left(93.2 \mathrm{~kg}\right.$ ha- $\left.\mathrm{cm}^{-1}\right)$. Lower WUE $\left(33.6 \mathrm{~kg} \mathrm{ha}-\mathrm{cm}^{-1}\right.$ in pooled analysis) was noticed in drip irrigation with soil application of fertilizers (control) and absolute control (20.1 kg ha- $\mathrm{cm}^{-1}$ in pooled analysis).

Increase in water use efficiency was attributed to increased grain yield with decreased water consumption as compared to drip irrigation scheduling at $150 \%$ PE throughout the growth 
stages. In the present investigation, $150 \%$ PE throughout the growth stages with soil application of fertilizers consumed higher amount of water $(116.32 \mathrm{~cm})$ with significantly lower yield which resulted in lower water use efficiency which might be due to increased leaching and volatilization losses of nitrogen. The increase in water use efficiency in all drip fertigated treatments over soil application of fertilizers was mainly due to considerable saving of water and nutrients, greater increase in yield of crop and higher nutrient use efficiency as a result of timely, sufficiently and frequent supplementation of water and nutrient to root zone leading to the decrease in leaching and volatilization losses of nitrogen.. This was in accordance with Gururaj (2013) and Anusha (2015) in rice. These studies reveal that supplying water to soil and nearer to the plant with sufficient quantities resulting in higher water use efficiency.

\section{Economics}

The economics of aerobic rice cultivation differed due to precision management practices with respect to gross return, which was a result of prices and yield of marketable produce, cost of cultivation which varied in relation to different inputs used, and in turn net returns and $\mathrm{B}$ : $\mathrm{C}$ ratio (Table 3). Pooled data indicated that, higher gross return, net return and B:C ratio was recorded ( $\square$ 1,39,080 $\mathrm{ha}^{-1}, \square \quad 82,853 \mathrm{ha}^{-1}$ and 2.47, respectively) in application of $25 \% \mathrm{~N} \& \mathrm{~K}$ from sowing to $30 \mathrm{DAS}+25 \% \mathrm{~N} \& \mathrm{~K}$ from 31 to $50 \mathrm{DAS}+25 \% \mathrm{~N} \& \mathrm{~K}$ from 51 to 80 DAS $+25 \% \mathrm{~N} \& \mathrm{~K}$ from 81 to $105 \mathrm{DAS}$ with planting geometry of $25 \times 15 \mathrm{~cm}$ with drip irrigation scheduling at $125 \% \mathrm{PE}$ up to tillering $+150 \%$ PE from tillering to PI + $200 \%$ PE from PI to physiological maturity. Lower gross return, negative net return and $\mathrm{B}$ : $\mathrm{C}$ ratio was recorded by absolute control ( $\square$ $37,192 \mathrm{ha}^{-1} \square-1,643 \mathrm{ha}^{-1}$ and 0.96, respectively) in pooled data. This was mainly due to reduced grain and straw yield and increased cost of cultivation.

In conclusion, Precision management practices in combination of $25 \times 15 \mathrm{~cm}$ planting geometry and drip irrigation scheduling at $125 \% \mathrm{PE}$ up to tillering + $150 \%$ PE from tillering to PI $+200 \%$ PE from PI to physiological maturity along with application of $\mathrm{N}$ and $\mathrm{K}$ in four splits up to 105 DAS through drip fertigation was the best precision management practice for achieving higher grain yield, net returns and $\mathrm{B}$ : $\mathrm{C}$ ratio.

\section{Acknowledgment}

The authors are grateful to the RKVY project on "Enhancing water productivity in command areas of Karnataka" for providing the financial assistance to carry out this work as part of my $\mathrm{Ph} . \mathrm{D}$ research programme.

\section{References}

Anusha, S., Nagaraju, Shankaralingappa, B.C., Sheshadri, T., Channabasavegowda, R., Shankar, A.G. and Mallikarjuna, G.B. 2015. Influence of fertigation intervals and fertilizer combinations on growth and yield of direct seeded drip irrigated aerobic rice. The Ecoscan, 9(1\&2): 299-303.

Bouman, B.A.M., Humphreys, E., Tuong, T.P. and Barker, R. 2007. Rice and water. Adv. Agron., 92: 187-237.

Cantrell, R.P. and Teeves, T.G. 2002. The cereal of the world's poor takes centre stage. Science, 296: 53.

Crookston, K. 2006. A top 10 list of developments and issues impacting crop management and ecology during the past 50 years. Crop Sci. 46, 2253-2262.

Gururaj, K. 2013. Optimization of water and nutrient requirement through drip fertigation in aerobic rice. M.Sc. (Agri.) 
Thesis, Univ. of Agril. Sci., Bengaluru.

Hedley, C.B. and Yule, I.J. 2009. Soil water status mapping and two variable-rate irrigation scenarios. Precis. Agric., 10: 342-355.

Khavita, M.P. and Balasubramanian, R. 2008. Maximizing hybrid rice productivity through nitrogen and potassium. Crop Res., 35(3): 169-171.

Laborte, A.G., de Bie, K., Smaling, E.M.A., Moya, P.F., Boling, A.A. and van Ittersum, M.K. 2012. Rice yields and yield gaps in South East Asia: past trends and future outlook. Eur. $J$. Agron., 36: 9-20.

Mahlein, A., Oerke, E., Steiner, U. and Dehne, H. 2012. Recent advances in sensing plant diseases for precision crop protection. Eur. J. Plant Pathol, 133: 197-209.

Miao, Y., Mulla, D.J. and Robert, P.C. 2006. Spatial variability of soil properties, corn quality and yield in two Illinois, USA fields: implications for precision corn management. Precis. Agric. 7: 520.

Mueller, N.D., Gerber, J.S., Johnston, M., Ray, D.K., Ramankutty, N. and Foley, J.A. 2012. Closing yield gaps through nutrient and water management. Nature, 490: 254-257.

Normile, D. 2008. Reinventing rice to feed the world. Science, 321: 330-333.

Peng, S., Buresh, R.J., Huang, J., Zhong, X., Zou, Y., Yang, J., Wang, G., Liu, Y., Hu, R., Tang, Q., Cui, K., Zhang, F. and
Dobermann, A. 2010. Improving nitrogen fertilization in rice by sitespecific $\mathrm{N}$ management. A review. Agron. Sustain. Dev., 30: 649-656.

Raina, J.N., Sharma, T. and Suman, S. 2011. Effect of drip fertigation with different fertilizers on nutrient distribution in soil, leaf nutrient content and yield of apricot (Prunus aremeniaca L.). J. Indian Soc. Soil Sci., 59: 268-277.

Ranjith, T.M. 2015. Standardisation of planting geometry in aerobic rice (Oryza sativa L.) under different levels of drip fertigation. M.Sc (Agri.) Thesis, Univ. of Agril. Sci., Bengaluru.

Shen, J., Cui, Z., Miao, Y., Mi, G., Zhang, H., Fan, M., Zhang, C., Jiang, R., Zhang, W., Li, H., Chen, X., Li, X. and Zhang, F. 2013. Transforming agriculture in China: from solely high yield to both high yield and high resource use efficiency. Global Food Security, 2: 18.

Sultana, M.R., Rahman, M.M. and Rahman, M.H. 2012. Effect of row and hill spacing on the yield performance of boro rice (cv. BRRI dhan45) under aerobic system of cultivation. $J$. Bangladesh Agril. Univ., 10(1): 39-42.

Tilman, D., Balzer, C., Hill, J. and Befort, B.L. 2011. Global food demand and the sustainable intensification of agriculture. Proc. Natl. Acad. Sci. U.S.A. 108, 20260-20264.

\section{How to cite this article:}

Prabhudeva, D.S., Nagaraju, T. Sheshadri, P.K. Basavaraja, M.N. Thimmegowda and Mallikarjuna, G.B. 2017. Precision Management Practices - A Much Needed Set of AgroTechniques to Improve Rice Productivity and Cutback the Resources in Aerobic Condition under Drip Irrigation. Int.J.Curr.Microbiol.App.Sci. 6(8): 2800-2810. doi: https://doi.org/10.20546/ijcmas.2017.608.333 